\title{
Spatiaalinen vaihtelu ja kasvin kasvun mallinnus
}

\author{
Mikko Hakojärvi ${ }^{1}$, Mikko Hautala ${ }^{1}$, Antti Ristolainen ${ }^{2}$, Berit Mannfors ${ }^{1}$, Laura Alakukku ${ }^{1}$ \\ ${ }^{1}$ Maataloustieteiden laitos, PL28, 00014 Helsingin Yliopisto, mikko.hakojarvi@helsinki.fi, \\ mikko.hautala@helsinki.fi,berit.mannfors@helsinki.fi,laura.alakukku@helsinki.fi \\ ${ }^{2}$ MTT, Planta, 31600 Jokioinen, antti.ristolainen@mtt.fi
}

\section{Tiivistelmä}

Täsmäviljelyn perustana on viljellä peltoa paikkakohtaisesti viljelykasvin tarpeiden mukaisesti. Vesi on yksi tärkeimmistä kasvin kasvua määrittävistä tekijöistä lämmön, auringon säteilyn ja ravinteiden ohella. Kasville käytettävissä olevan veden määrä määräytyy sateiden ja maan hydrologisten ominaisuuksien perusteella. Tästä syystä paikkakohtainen tieto maaperän ominaisuuksista on olennaista täsmäviljelyssä.

Suomessa kasvuolot vaihtelevat paljon kasvukausien välillä, mikä heijastuu myös viljelykasvin kasvuun. Tämä puolestaan vaikeuttaa viljelypanosten määrän mitoittamista kuluvan kasvukauden oloja vastaavaksi. Tämä muodostuu ongelmaksi erityisesti lannoituksessa, joka on kevätviljoilla perinteisesti tehty kylvön yhteydessä, jolloin on mahdotonta ennustaa luotettavasti tulevan kasvukauden olosuhteita. Yksi mahdollinen ratkaisu voisi olla lannoitteen jakaminen kahdessa tai useammassa eri erässä. Tällöin myöhemmillä lannoituskerroilla pystyttäisiin ottamaan huomioon kasvukauden siihen astiset kasvuolot sekä myös säätämään lannoitteen määrää paikkakohtaisesti kasvien tarpeen mukaan. Säädön myötä tarvittavan lannoitteen määrä ei välttämättä kaikissa tapauksissa pienene, mutta se pystytään kohdentamaan niihin pellon osiin, joissa viljelykasvi kykenee sen parhaiten hyödyntämään. Jotta tällainen säätö olisi mahdollista, tarvitaan malli, jolla voidaan verrata havaittua kasvua maksimaaliseen kasvuun sekä estimoida kasvin tulevaa kasvua ja tarvetta kasvuresursseille.

Maataloustieteiden laitoksella TOOLMOD projektissa yksi tutimuksen kohden on ollut täsmäviljelyn työkaluksi tarkoitettu kasvimalli, jota käytettiin myös tässä tutkimuksessa. Malli on rakenteeltaan mekanistinen ja sillä pystytään kuvaamaan C3-kasvien biomassan kertymistä. Malli on tarkoitettu työkaluksi, jolla pystytään mitoittamaan paikkakohtaista lisälannoituksen määrää kasvukauden aikana. Tarvittavan lisälannoituksen määrä määräytyisi mallin antaman kasvun sekä pellolla kasvustosta mitatun säteilyn käytön perusteella. Tässä tutkimuksessa tutkittiin kasvimallin toimivuutta paikkakohtaisesti MaSa-projektissa kerätyn aineiston avulla. Tutkimuksessa käytettiin kolmen eri savipellon havaintoja kolmelta peräkkäiseltä vuodelta. Aineiston avulla selvitetttiin kuinka suuri osuus pelloilta havaituista satovaihtelusta voidaan selittää maaperästä mitatuilla suureilla kyseisen mallin avulla.

Asiasanat: Savimaa, tilavaihtelu, kevätvilja, mallinnus 


\section{Johdanto}

Jos ajatellaan viljelykasvia systeeminä, havaitaan nopeasti sen olevan hyvin herkkä kasvuolosuhteille, kuten esimerkiksi säälle, maaperälle ja ravinteille. Kasvi sopeutuu hyvin erilaisiin kasvuolosuhteisiin muuttamalla muotoaan eri tavoin kuten lisäämällä juuriston kasvua kuivuuden uhatessa. Tämä ominaisuus tekee kasvin selviytymisen luonnossa mahdolliseksi, mutta vaikeuttaa kasvin kasvun mallinnusta huomattavasti. Jotta kasvin luonnollinen monimuotoisuus voitaisiin kuvata matemaattisella mallilla, täytyisi tämän mallin olla valtava kokoelma kaavoja kuvailemaan kasvin sisältämiä prosesseja. Käytännössä tällainen malli kuitenkin vaatisi huomattavan määrä kasvupaikoista kerättyä tietoa, jotta mallia voitaisiin käyttää esimerkiksi täsmäviljelyn työkaluna paikkakohtaisia viljelytoimenpiteitä suunniteltaessa.

Maantieteellinen sijainti, maalaji ja auringon paiste ovat pellolle suhteellisen pysyviä ominaisuuksia, koska pellon pinnan muodot ja ympäröivät metsät muuttuvat niin hitaasti, että niiden voidaan olettaa pysyvän muuttumattomina. Maan rakenne puolestaan muuttuu vuodesta toiseen muokkauksesta, viljelykasvista ja peltoliikenteestä riippuen. Sää on ehkä kaikista eniten muuttuva tekijä vuosien välillä. Kaikki nämä tekijät yhdessä muodostavat viljelykasville kasvuolosuhteet, jotka vaihtelevat vuodesta toiseen. Vuosien välinen vaihtelu ei kuitenkaan tule yksistään sään vaihtelusta, vaan sään ja paikkakohtaisten ominaisuuksien yhteisvaikutuksesta. Maalaji yhdessä maan rakenteen ja kasvin vedenkulutuksen kanssa määrittelevät sen sateen määrän, mikä on viljelykasville liikaa ja kuinka paljon on sopivasti.

Tässä tutkimuksessa tutkitaan maan spatiaalisten ominaisuuksien vaikutusta viljelykasvin kasvuun ja edelleen sen mallintamista kasvimallin avulla. Kasvimallina käytetään mallia, joka on rakenteeltaan mahdollisimman yksinkertainen, sisältää mahdollisimman vähän parametreja ja vain sellaisia parametreja joilla on selkeä fysikaalis-kemiallis-biologinen merkitys. Koeaineistona tutkimukselle toimii aiemmissa MaSa-projekteissa kerätty informaatio, josta tähän tutkimukseen valittiin savipelloilta kerätty informaatio. Tutkimuksen aineistosta valittiin savipellot siksi, että niissä maaperän ominaisuuksien vaihtelu heijastuu selkeästi viljelykasvin kasvuun.

\section{Aineisto ja menetelmät}

Tässä tutkimuksessa hyödynnettiin aiemmin päättyneissä MaSa 1 (2002-2004) ja MaSa 2 (20062008) projekteissa kerättyä paikkakohtaista informaatiota maaperästä ja kasvin kasvusta. Molemmissa projekteissa kerättiin paikkakohtaista informaatiota kolmen peräkkäisen vuoden ajan yhteensä kuutta eri peltolohkolta. Näistä kuudesta pellosta tähän tutkimukseen valittiin kolme peltoa (J1, J2 ja Vihti), joissa saves-pitoisuus oli korkea (J1:n maalaji HtS-As, J2:n As, Vihdin HHt-HsS). Näistä kolmesta valitusta pellosta Jokioisilla sijainneet J1 ja J2 pellot olivat lähimpänä toisiaan sekä maalajiltaan että maantieteelliseltä sijainniltaan. Kolmas valittu lohko sijaitsi etäämmällä Vihdissä. Suurimmat erot peltojen välillä sekä peltojen sisäisten havaintopisteiden välillä olivat maan rakenteessa.

Valituilla pelloilla viljeltiin koejakson aikana valtaosin ohraa (Hordeum vulgare L, lajikkeet Inari, Saana and Prestige). Poikkeuksena kuitenkin pelto Vihti ja vuosi 2007, jolloin kyseisellä pellolla viljeltiin kevätrypsiä (Brassica rapa oloiferea). Paikkakohtaista informaatiota pelloilta kerättiin vuosittain useista havaintopisteistä, joita oli pellolla J1 $20 \mathrm{kpl}$, pellolla J2 $21 \mathrm{kpl}$ ja pellolla Vihti 24 kpl. Havaintopisteiden sijainti määritettiin GPS:n avulla, jolloin voitiin varmistua siitä, että eri vuosina havaintoja tehtiin samoista paikoista. Valituista pisteistä määritettiin $\mathrm{mm}$. kylläisen maan vedenjohtavuus, vesipitoisuudet imuissa $0 \mathrm{kPa},-10 \mathrm{kPa}$ ja $-1500 \mathrm{kPa}$. Syvyyssuuntaisen vaihtelun määrittämiseksi maaperästä tehdyt määritykset tehtiin pelloille $\mathrm{J} 1$ ja $\mathrm{J} 2$ kolmelle syvyydelle (muokkauskerros 0-20 cm, kyntöantura $20-35 \mathrm{~cm}$, pohjamaa $35-60 \mathrm{~cm}$ ) ja pellolle Vihti kahdelle syvyydelle (pintamaa $5-10 \mathrm{~cm}$ ja pohjamaa $35-40 \mathrm{~cm}$ ).

\section{Mittaukset kasvukaudella}

Havaintopisteiden kohdalta kasvustosta määritettiin viljelykasvin biomassa tähkälletulovaiheessa sekä jyväsato. Lisäksi näistä pisteistä mitattiin kasvukauden aikana viljelykasvin lehtialan ja maan kosteuden kehitystä TDR-menetelmällä kahdesta eri syvyydestä $(0-30 \mathrm{~cm}$ ja $0-60 \mathrm{~cm})$. Koevuosien 2002-2004 säätieto saatiin koepeltojen läheisyydessä sijainneelta Ilmatieteen laitoksen sääasemalta, 
jota voitiin hyödyntää peltojen J1 ja J2 simuloinneissa. Samoin koevuosien 2006-2008 säätieto saatiin koepellon läheisyydessä sijainneelta Ilmatieteen laitoksen sääasemalta, jota voitiin simuloinneissa hyödyntää pellolle Vihti.

\section{Kasvinkasvumalli}

Tässä tutkimuksessa käytettiin kasvimallia, joka kuvaa C3 kasvin potentiaalisen biomassan kertymistä vallitsevissa kasvuoloissa. Käytetty kasvimalli poikkeaa muista käytössä olevista malleista parametrien määrässä; niitä on hyvin vähän ja niillä on selkeä fysikaalinen merkitys, minkä ansiosta ne ovat myös mitattavissa käytännön olosuhteissa (Hautala ja Hakojärvi, 2010). Koska malli laskee potentiaalisen biomassan kertymistä, se ei ota huomioon muita kasvun rajoitteita kuin auringon säteilyn ja veden. Malli ei myöskään sisällä siemenen itämistä, vaan mallissa alkuhetkellä viljelykasvin siemen on jo itänyt ja luokitellaan taimeksi.

Koska kasvimalli kuvaa vain kasvin itsensä kasvamista ja biomassan kertymistä, tarvitaan maaperälle oma mallinsa. Tässä tutkimuksessa maaperällekin käytettiin rakenteeltaan yksinkertaisinta mahdollista mallia, jota kutsutaan ns. astiamalliksi. Tässä mallissa maaperä jaetaan syvyydessä useisiin kerroksiin, joiden paksuus oli $10 \mathrm{~cm}$. Jokainen kerros sai omat arvonsa seuraaville parametreille: kylläisen maan vedenjohtavuus $\left(\mathrm{K}_{\mathrm{sat}}\right)$, kylläinen kapasiteetti $(\mathrm{SWC}, 0 \mathrm{kPa})$, kenttäkapasiteetti (FC, -10 kPa) ja lakastumisraja (PWP, -1500 kPa). Parametrit SWC, FC ja PWP kuvaavat maan vesipitoisuutta vähenevässä järjestyksessä eli SWC on yläraja, jota korkeammaksi kerroksen vesipitoisuus ei voi nousta. FC puolestaan kertoo kuinka alas kosteuspitoisuus laskee, kun painovoimainen vesi maasta poistuu. PWP taas kertoo kuinka suuri osuus maan vedestä on sitoutunut maahan niin tiukasti, ettei se ole kasville käyttökelpoista. Tämän maaperämallin perusoletus on, että vesi ei liiku maan kosteuspitoisuuden ollessa kenttäkapasiteetin alapuolella. Tämä perustuu siihen, että kuivassa savimaassa vesi liikkuu alaspäin niin hitaasti, ettei sen huomioimatta jättäminen aiheuta merkittävää muutosta lopputulokseen.

\section{Tulokset ja tulosten tarkastelu}

\section{Maaperän ominaisuudet}

Koepelloilta mitattujen ominaisuuksien arvoissa havaittiin eroja sekä peltojen sisällä, että eri peltojen välillä (Taulukko 1). Parhaiten lohkojen väliset erot maanperän ominaisuuksissa näkyvät kylläisen maan vedenjohtavuudessa, joiden perusteella pelto $\mathrm{J} 2$ erottuu selkeästi huonoiten vettä johtavaksi pelloksi. Samoin pellon J2 saamat arvot maan vesipitoisuuksille eri maaveden potentiaaleissa ovat kahta muuta peltoa korkeammalla. Näiden lukujen perusteella voidaan päätellä pellon J2 olevan altis liiallisen kosteuden aiheuttamille ongelmille sateisina kasvukausina.

Taulukko 1. Koepelloista mitattuja maaperän hydrologisten ominaisuuksien arvoja (keskiarvo ja hajonta $\sigma$ ). Taulukon arvoja käytettiin myös maaperämallin parametrien arvoina.

\begin{tabular}{|c|c|c|c|c|c|c|c|c|}
\hline \multirow[t]{2}{*}{$\begin{array}{l}\text { Peltolohko } \\
\text { Syvyys (m) }\end{array}$} & \multicolumn{2}{|c|}{$\begin{array}{l}\operatorname{SWC}(\psi=0 \mathrm{kPa}) \\
\text { Kosteus }\left(\mathrm{m}^{3} / \mathrm{m}^{3}\right)\end{array}$} & \multicolumn{2}{|c|}{$\begin{array}{l}\mathrm{FC}(\psi=-10 \mathrm{kPa}) \\
\text { Kosteus }\left(\mathrm{m}^{3} / \mathrm{m}^{3}\right)\end{array}$} & \multicolumn{2}{|c|}{$\begin{array}{c}\text { PWP }(\psi=-1500 \mathrm{kPa}) \\
\text { Kosteus }\left(\mathrm{m}^{3} / \mathrm{m}^{3}\right)\end{array}$} & \multicolumn{2}{|c|}{$\begin{array}{c}\mathrm{K}_{\mathrm{sat}} \\
(\mathrm{cm} / \mathrm{h})\end{array}$} \\
\hline & Keskiarvo & $\sigma$ & Keskiarvo & $\sigma$ & Keskiarvo & $\sigma$ & Keskiarvo & $\sigma$ \\
\hline \multicolumn{9}{|l|}{ J1 } \\
\hline $0-0,20$ & 0,491 & 0,018 & 0,398 & 0,021 & 0,220 & 0,013 & 80,6 & 72,0 \\
\hline $0,20-0,35$ & 0,474 & 0,022 & 0,429 & 0,026 & 0,290 & 0,034 & 58,1 & 84,8 \\
\hline $0,35-0,60$ & 0,474 & 0,034 & 0,438 & 0,039 & 0,314 & 0,028 & 1,0 & 1,0 \\
\hline \multicolumn{9}{|l|}{$\mathrm{J} 2$} \\
\hline $0-0,20$ & 0,553 & 0,028 & 0,460 & 0,035 & 0,256 & 0,035 & 39,7 & 39,6 \\
\hline $0,20-0,35$ & 0,532 & 0,040 & 0,502 & 0,048 & 0,355 & 0,035 & 5,4 & 13,2 \\
\hline $0,35-0,60$ & 0,541 & 0,032 & 0,526 & 0,035 & 0,397 & 0,033 & 0,2 & 0,7 \\
\hline \multicolumn{9}{|l|}{ Vihti } \\
\hline $0,05-0,10$ & 0,480 & 0,021 & 0,394 & 0,038 & 0,233 & 0,041 & 463,1 & 936,0 \\
\hline $0,35-0,40$ & 0,458 & 0,027 & 0,407 & 0,045 & 0,254 & 0,046 & 155,1 & 535,8 \\
\hline
\end{tabular}




\section{Sato vs. maan ominaisuudet}

Tarkasteltaessa maaperästä mitattujen ominaisuuksien ja havaittujen satojen välisiä suhteita huomattiin, että korrelaatiot näiden välillä olivat heikkoja (Kuva 1). Tämä saattoi osaltaan johtua siitä, että maaperän ominaisuudet mitattiin vain yhtenä koejakson vuotena. Maanäytteiden ottaminen ja käsitteleminen on kuitenkin hyvin työlästä ja aikaa vievää, mistä johtuen niiden vuosittainen tekeminen on ajankäytöllisesti ja taloudellisesti kyseenalaista kuten aiemmissakin tutkimuksissa on todettu (Earl ym. 2003). Toisaalta maaperässä muutokset voivat olla lähinnä vain rakenteellisia muutoksia, esimerkiksi maalajin pysyessä ennallaan ja orgaanisen aineksen osuudenkin muuttuvan hitaasti. Maan muokkauksesta ja viljelykierrosta riippuen muutokset pinta-maan rakenteessa voivat olla suuriakin, mutta muokkaus syvyyden alapuolella muutokset maan ominaisuuksissa olisivat oletettavasti pieniä. Edelleen koko maaprofiilia viljelykasvin kasvun kannalta ajatellen tilanne ei tästä ratkaisevasti muuttuisi paitsi hyvin sateisissa oloissa, koska kylläisen maan vedenjohtavuus on hyvin voimakkaasti riippuvainen maan rakenteesta.
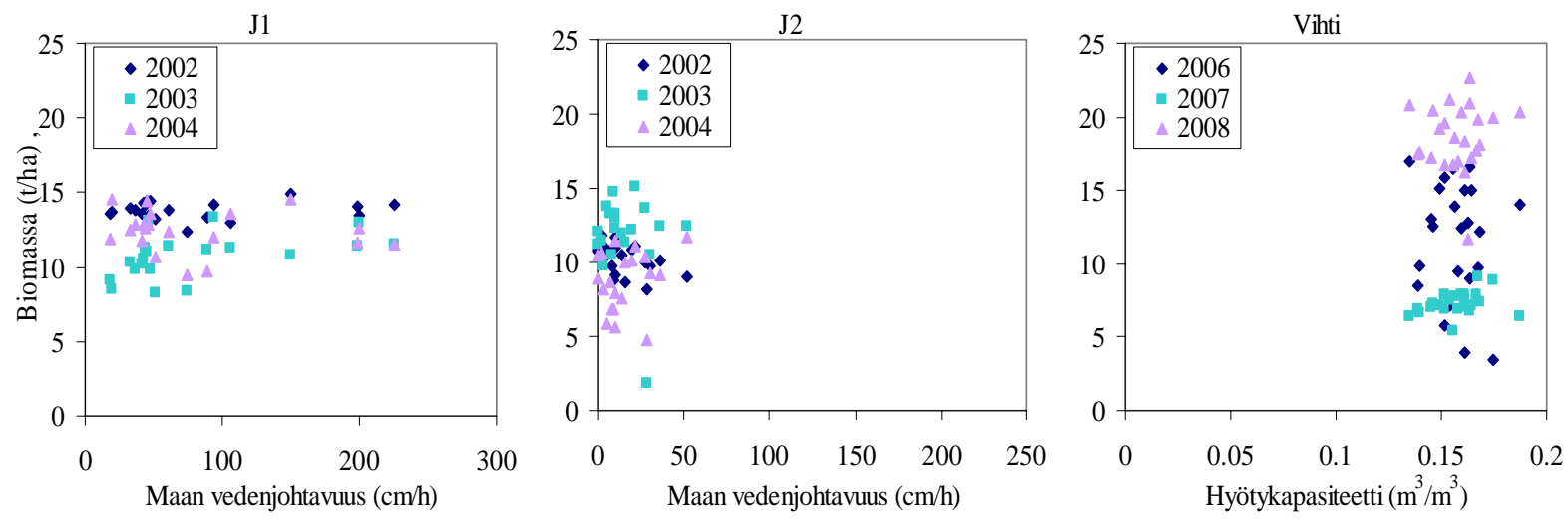

Kuva 1. Peltojen $\mathbf{J} 1$ ja $\mathbf{J} 2$ havaintopisteiden biomassasadot kylläisen maan vedenjohtavuuden $\left(\mathrm{K}_{\mathrm{sat}}\right)$ funktioina sekä pellon Vihti havaintopisteiden biomassa sadot hyötykapasiteetin (FC-PWP) funktiona.

Havaintopistekohtaiset arvot kylläisen maan vedenjohtavuudelle ja hyötykapasiteetille ovat syvyydellä painotettuja keskiarvoja, jotka on laskettu kolmesta eri syvyydestä (Taulukko 1) mitatusta arvoista.

Kuvan 1 kaltainen heikko korrelaatio maaperästä mitattujen arvojen ja havaitun biomassan välillä toistui myös vertailtaessa simuloitua ja havaittua biomassaa (Kuva 2). Koska mallin avulla lasketaan potentiaalista eli suurinta saavutettavissa olevaa biomassaa, simuloitua ja havaittua biomassaa ei suoraan voida tutkia korrelaation avulla, koska tulosten ei välttämättä tarvitse olla lineaarisesti toisistaan riippuvia tai yhteneviä. Ero simuloidun ja havaitun biomassan välillä kertoo siitä, että jokin muu kuin mallissa huomioitu tekijä on rajoittanut viljelykasvin kasvua. Tämä pätee osittain myös kosteuteen, sillä malli ei ota huomioon liiallisen veden vaikutusta kasvuun. Tutkimuksen tavoitteena oli selvittää kuinka suuri osuus havaitusta biomassasadon hajonnasta voidaan selittää mallin avulla havaintopisteistä kerättyä tietoa käyttäen. Taulukosta 2 voidaan havaita mallin tuottaneen aina havaittua pienemmän hajonnan yhtä poikkeusta lukuunottamatta (Vihti, 2008). Käytännössä taulukon 2 tulokset tarkoittavat sitä, että vain osa satovaihtelusta kyetään selittämään maan ominaisuuksien perusteella. Epävarmuutta tähän tulokseen lisää se, että simuloinneissa käytettiin samoja taimitiheyksiä kaikille havaintopisteille, mikä ei välttämättä vastaa todellisuutta. 
Taulukko 2. Peltojen vuosittaiset havainopistekohtaiset sadot ( $\mathrm{t} / \mathrm{ha}$ ) hajontoineen ( $\mathrm{t} / \mathrm{ha})$ sekä havaittuna että simuloituna. Sadossa on mukana koko tuotettu biomassa: kasvin maanpäällinen biomassa sekä juuret.

$\mathrm{J} 1$

\begin{tabular}{|l|c|c|}
\hline \multicolumn{1}{|c|}{2002} & Keskiarvo & $\sigma$ \\
\hline Mitattu & 13,8 & 0,58 \\
\hline Simuloitu & 13,1 & 0,50 \\
\hline
\end{tabular}

\begin{tabular}{|l|c|l|}
\hline \multicolumn{1}{|c|}{2003} & Keskiarvo & \multicolumn{1}{l|}{$\sigma$} \\
\hline Mitattu & 10,7 & 1,48 \\
\hline Simuloitu & 11,5 & 0,46 \\
\hline
\end{tabular}

\begin{tabular}{|l|c|l|}
\hline \multicolumn{1}{|c|}{2004} & Keskiarvo & \multicolumn{1}{l|}{$\sigma$} \\
\hline Mitattu & 12,4 & 1,43 \\
\hline Simuloitu & 13,8 & 0,43 \\
\hline
\end{tabular}

$\mathrm{J} 2$

\begin{tabular}{|l|c|l|}
\hline \multicolumn{1}{|r|}{2002} & Keskiarvo & \multicolumn{1}{l|}{$\sigma$} \\
\hline Mitattu & 10,2 & 1,03 \\
\hline Simuloitu & 12,6 & 0,88 \\
\hline
\end{tabular}

\begin{tabular}{|l|c|l|}
\hline \multicolumn{1}{|c|}{2003} & Keskiarvo & $\sigma$ \\
\hline Mitattu & 11,9 & 2,74 \\
\hline Simuloitu & 9,7 & 0,86 \\
\hline
\end{tabular}

\begin{tabular}{|l|c|l|}
\hline \multicolumn{1}{|c|}{2004} & Keskiarvo & \multicolumn{1}{l|}{$\sigma$} \\
\hline Mitattu & 8,8 & 2,04 \\
\hline Simuloitu & 14,7 & 0,60 \\
\hline
\end{tabular}

Vihti

\begin{tabular}{|l|c|c|}
\hline \multicolumn{1}{|c|}{2006} & Keskiarvo & $\sigma$ \\
\hline Mitattu & 11,6 & 3,97 \\
\hline Simuloitu & 8,3 & 0,66 \\
\hline
\end{tabular}

\begin{tabular}{|l|c|l|}
\hline \multicolumn{1}{|c|}{2007} & Keskiarvo & \multicolumn{1}{l|}{$\sigma$} \\
\hline Mitattu & 7,3 & 0,78 \\
\hline Simuloitu & 7,7 & 0,45 \\
\hline
\end{tabular}

\begin{tabular}{|l|c|l|}
\hline \multicolumn{1}{|c|}{2008} & Keskiarvo & \multicolumn{1}{l|}{$\sigma$} \\
\hline Mitattu & 18,6 & 2,23 \\
\hline Simuloitu & 13,4 & 0,72 \\
\hline
\end{tabular}

Pellon J2 kohdalla simuloidun sadon hajonta oli lähimpänä havaittua hajontaa koejakson vähäsateisimpana $(183,9 \mathrm{~mm})$ vuotena. Kahdella muulla pellolla suurin simuloitu hajonta ei kuitenkaan ajoittunut kasvukauden sadannan mukaan. Tämän saattaa johtua yleisesti alhaisesta vedenjohtavuudesta pellolla J2. Pelloilla J1 ja Vihti mitattu vedenjohtavuus oli huomattavasti pellon J2 tasoa korkeampi, minkä ansiosta näillä kahdella pellolla kasvuolojen pitäisi pysyä kasville edullisempina myös sateisina kasvukausina. Maaperän hyötykapasiteetilla on myös oma vaikutuksensa sademäärien vaikutuksessa satoon, mutta peltojen väliset erot olivat kylläisen maan vedenjohtavuuteen nähden pieniä (data ei esitetty).

Selkeimmin hydraulisen vedenjohtavuuden vaikutus satoon on nähtävissä Kuvan 2 tuloksissa, joissa havaittu biomassa on jäänyt alhaiseksi useissa havaintopisteissä, joissa myös $\mathrm{K}_{\text {sat }}$ on ollut alhainen. Tämä ei kuitenkaan ole yksiselitteistä, sillä muutamassa havaintopisteessä vaikutus on ollut päinvastainen. Tuloksia tarkasteltaessa on otettava huomioon myös se, että mallissa käytettävät paikkakohtaiset parametrit ovat maaperän parametreja, koska kasvimallin parametrien arvoja ei ollut mahdollista laskea kerätystä informaatiosta. Tästä johtuen esimerkiksi mahdolliset paikkakohtaiset eroavuudet taimitiheyksissä eivät ole mallin syöttötietoina, eivätkä esimerkiksi itämisvaiheessa aiheutuneet erot taimitiheyksissä ole ole mukana mallin tuloksissa.

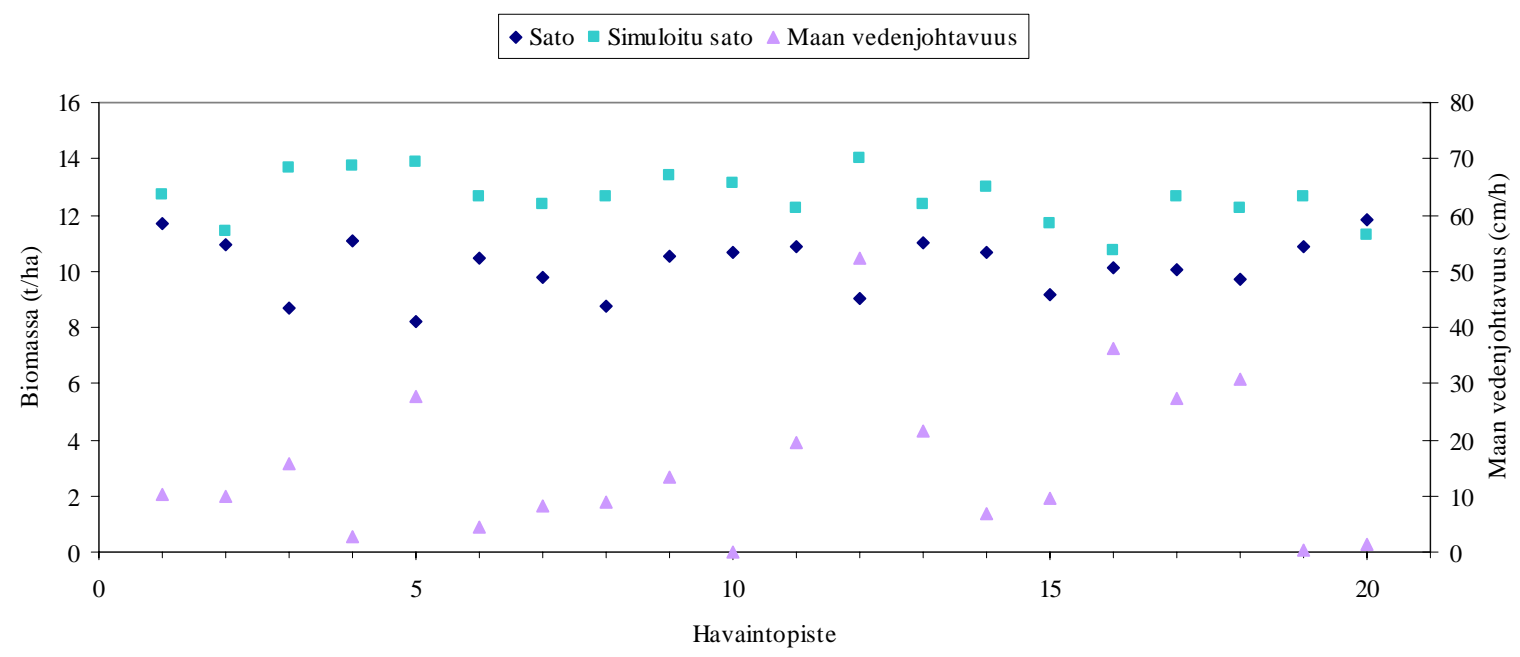

Kuva 2. Havaittu ja simuloitu biomassa sadonkorjuuhetkellä pellon J2 eri havaintopisteissä sekä maaperästä mitattu kylläisen maan vedenjohtavuus $\left(\mathrm{K}_{\mathrm{sat}}\right)$. Kylläisen maan vedenjohtavuus on syvyydellä painotettu keskiarvo, joka on laskettu kolmesta eri syvyydestä (Taulukko 1) mitatusta arvoista. Koejakson kuivin vuosi (2002) pellolle J2, jolloin kasvukauden sadesumma oli 183,9 mm. 
Huomattavaa on myös edellä havaitun ilmiön riippuvuus kasvukauden sademäärästä. Esimerkiksi sadon ja kylläisen maan vedenjohtavuuden välistä riippuvuutta ei ollut havaittavissa koejakson vuosina, joina sateen määrä oli pienempi. Vähäsateisina koejakson vuosina muuttujien välinen yhteys saattoi olla joissain sijainneissa jopa päinvastainen. Tulos on yhtenevä aiempien tutkimustulosten kanssa (King ym. 2005) sekä looginen, koska vähäsateisena vuotena alhainen kylläisen maan vedenjohtavuus ei ole aiheuttanut liian kosteita kasvuoloja kasvin juurille, vaan on säilyttänyt suuremman osuuden sadevedestä kasvin juuriston syvyydellä ja täten edistänyt biomassan kertymistä (Kuva 2). Näissä olosuhteissa myös käytetyn kasvimallin antama biomassan kertymä kasvukaudelta on lähempänä havaittua, koska ollaan olosuhteissa, joissa veden saatavuus rajoittaa kasvin kasvua. Kuvan 2 mukaisesti simuloitu biomassa seuraa hyvin havaittua biomassaa, mistä voidaan päätellä, että kosteus on ollut kasvin kasvua rajoittanut tekijä useissa havaintopisteissä. Mallin suunniteltua hyötykäyttöä ajatellen tämä on olennaista, sillä kuivissa olosuhteissa lannoitteen avulla ei voida saavuttaa lisäkasvua, vaikka lannoitteen levittäminen pellolle olisikin mahdollista. Märissä olosuhteissa (Kuva 3) lisälannoitteella voisi niissä tapauksissa, joissa ravinteet rajoittavat viljelykasvin kasvua, saavuttaa lisäkasvua, mutta lannoitteen levittäminen pellolle voisi muodostua ongelmaksi.

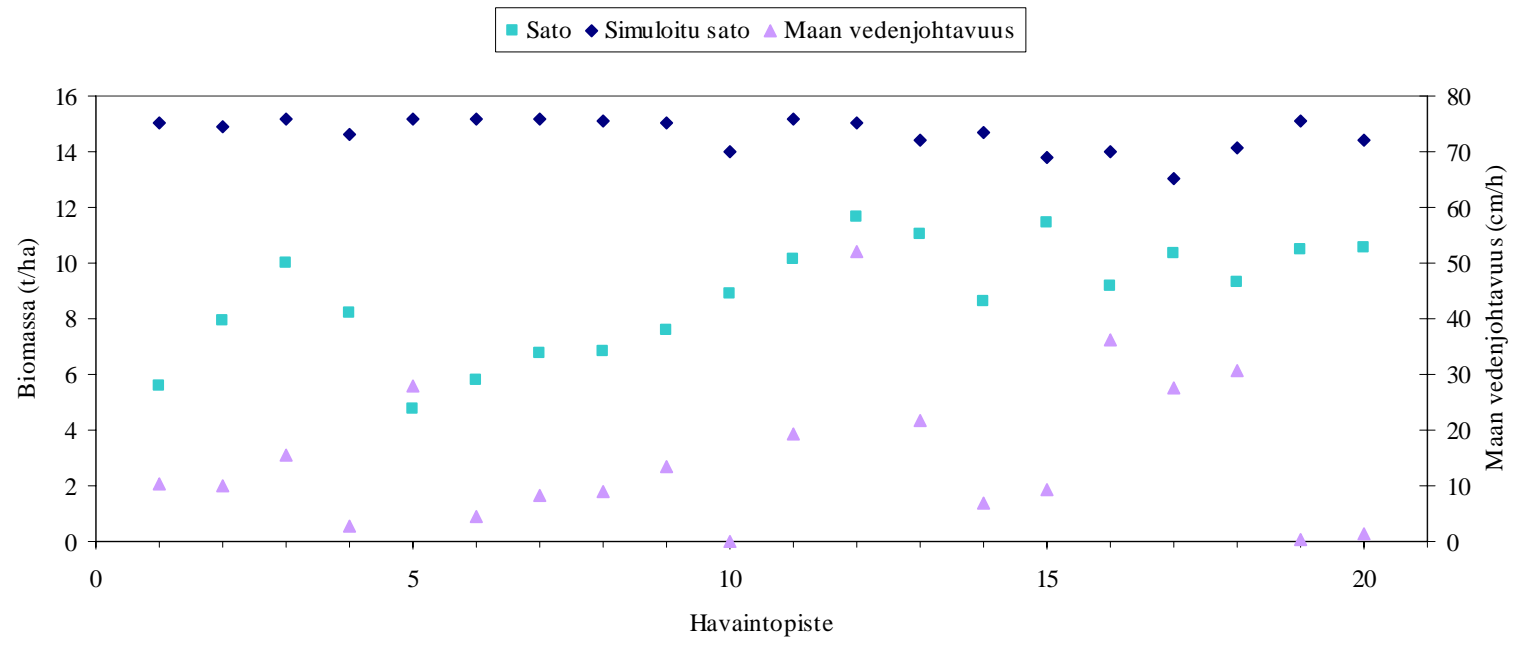

Kuva 3. Havaittu ja simuloitu biomassa sadonkorjuuhetkellä pellon $\mathrm{J} 2$ eri havaintopisteissä sekä maaperästä mitattu kylläisen maan vedenjohtavuus $\left(\mathrm{K}_{\mathrm{sat}}\right)$. Kylläisen maan vedenjohtavuus on syvyydellä painotettu keskiarvo, joka on laskettu kolmesta eri syvyydestä (Taulukko 1) mitatusta arvoista. Koejakson sateisin vuosi (2004) pellolle J2, jolloin kasvukauden sadesumma oli 334,1 mm.

Tarkasteltaessa hyötykapasiteetin vaikutusta havaintojen ja simulointien lopputuloksiin hyötykapasiteetin vaikutus oli havaittavissa (Kuva 4). Vaikutus oli kuitenkin heikko eikä kaikissa tapauksissa yhdenmukainen, kuten oli havaittavissa maan vedenjohtavuudenkin vaikutuksesta. Kaikenkaikkiaan tutkimuksen tulokset antavat viitteitä sitä, että maan ominaisuuksilla pystytään selittämään vain osa satovaihtelusta siitä huolimatta, että ne suurelta osin vaikuttavat kasvin veden saantiin ja kasvuoloihin. Tarkastelua vaikeuttaa se, että ainakin tämän aineiston perusteella vaikutus näyttää vaihtelevan vuosien välillä, mikä mahdollisesti riippuu sateen määrästä, mutta ei kuitenkaan ole säännöllistä tai lineaarista sateen määrään nähden. Tulos on linjassa aiempien tutkimusten kanssa, joissa on samoin kyetty osoittamaan sadon riippuvuus osittain maaperän ominaisuuksista (Lark ym. 1998, Taylor ym. 2003, King ym. 2005). Koska tuloksia tarkastellaan paikkakohtaisesti, on olennaista erotella koejakson vuodet erilleen, sillä muutoin saatetaan menettää arvokasta paikkakohtaista informaatiota (Sadler ym. 2007), joka usein näissä aineistoissa on se tärkein osuus mallin testaamisen kannalta. 


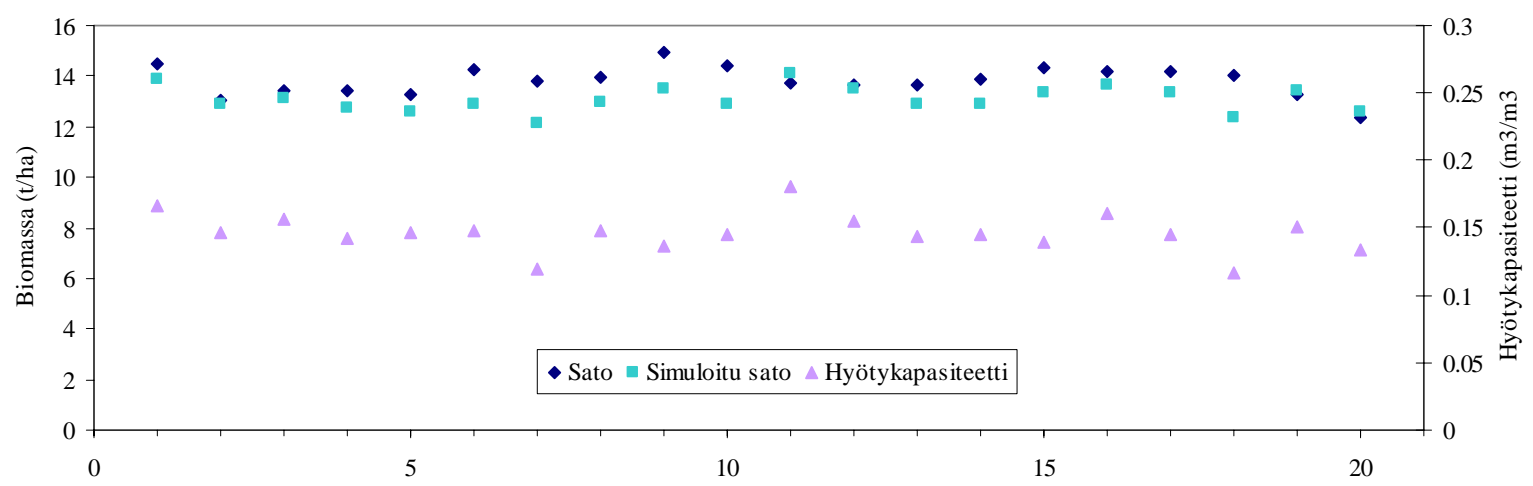

Kuva 4. Havaittu ja simuloitu biomassa sadonkorjuuhetkellä pellon J1 eri havaintopisteissä. Hyötykapasiteetti on syvyydellä painotettu keskiarvo, joka on laskettu kolmesta eri syvyydestä (Taulukko 1) mitatusta arvoista. Koejakson vuosi (2002) pellolle J1, jolloin kasvukauden sadesumma oli 188,2 mm.

\section{Johtopäätökset}

C3 kasvien biomassan kertymistä kuvaavaa mallia testattiin paikkakohtaisella informaatiolla kolmelta eri pellolta, joista jokaiselta informaatiota kerättiin kolmen peräkkäisen vuoden ajan. Malli tuotti suuruusluokaltaan miltei yhtä suuren biomassan hajonnan kuin havaitussakin aineistossa. Hajonta simulointituloksissa johtuu maaperän ominaisuuksista eli kylläisen maan vedenjohtavuudesta $\left(\mathrm{K}_{\mathrm{sat}}\right)$, kenttäkapasiteetista (FC) ja lakastumisrajasta (PWP), koska eri havaintopisteiden välillä muuttuivat vain näiden parametrien arvot muiden parametrien arvojen pysyessä ennallaan.

Simuloitujen biomassojen havaittiin olevan samalla tasolla havaittujen biomassojen kanssa kasvulle suotuisissa oloissa. Simuloitujen satojen hajonta oli yleisesti vähäisempää kuin hajonta havaituissa sadoissa, minkä oletetaan johtuvan osaksi siitä, että kasvimallille ei ollut käytettävissä paikkakohtaisia parametrien arvoja (esimerkiksi taimitiheys). Tulokset indikoivat mallin olevan käyttökelpoinen käytännön peltoviljelyn olosuhteissa, mutta toisaalta myös kertovat sen, että kovin tarkkaan lopputulokseen ei ole mahdollista päästä ilman kattavampaa paikkakohtaista informatiota.

\section{Kiitokset}

Tämän tutkimuksen rahoitti Maatalouskoneiden tutkimussäätiö. Maa- ja vesitekniikan tuki ry ja Maaja metsätalousministeriö rahoitti MaSa1 projektia, jossa kerättyä paikkakohtaista informaatiota käytettiin tässä tutkimuksessa. Kiitämme Marja-Liisa Westerlundia, Matti Ylösmäkeä ja Ilkka Sarikkaa ammattitaitoisesta työstä sekä kentällä, että laboratoriossa.

\section{Kirjallisuus}

Earl, R., Taylor, J., Wood, G., Bradley, I., James, I., Waine, T., Welsh, J., Godwin, R. \& Knight, S. 2003. Soil Factors and their Influence on Within-field Crop Variability, Part I: Observation of Soil Variation. Biosystems Engineering 84(4):425-440.

Hautala, M. \& Hakojärvi, M. 2010. An analytical C3-crop growth model for precision farming. Precision Agriculture, 12(2):266-279.

King, J., Dampney, P., Lark, R., Wheeler, H., Bradley, R. \& Mayr, T. 2005. Mapping Potential Crop Management Zones within Fields: Use of Yield-map series and Patterns of Soil Physical Properties Identified by Electromagnetic Induction Sensing. Precision Agriculture, 6(2):167-181.

Lark, R., Catt, J. \& Stafford, J. 1998. Towards the explanation of within-field variability of yield of winter barley: soil series differences. Journal of Agricultural Sciences, 131:409-416.

Sadler, J., Sudduth, K. \& Jones, J. 2007. Separating spatial and temporal sources of variation for model testing in precision agriculture. Precision Agriculture 8:297-310.

Taylor, J., Wood, G., Earl, R. \&Godwin, R. 2003. Soil Factors and their Influence on Within-field Crop Variability, Part II: Spatial Analysis and Determination of Management Zones. Biosystems Engineering 84(4):441-453. 